\title{
LOCALIZATION OF BIOGUMUS AND MINERAL COMPOUNDS IN DRUGS OF DIFFERENT SPECIES
}

\author{
Shevchuk T. ${ }^{1}$, Zavoloka G. ${ }^{2}$ \\ ${ }^{1}$ Vinnitsa National Agrarian University \\ st. Sonyachna, 3, 21000, m. Vinnitsya \\ ${ }^{2}$ Vinnitsa branch of the State Forest Enterprise "State Crop Protection" \\ st. Michurina, 3, 23227, v. Agronomichne, Vinnitsa region \\ tatjana.melnikova@ukr.net
}

\begin{abstract}
The article presents the results of experimental studies of biochemical composition and properties of silts of different species. The localization of humus, organic matter and individual minerals in silt of different species depending on depth of occurrence has been investigated. For analysis, biogenic, clastogenic and mixed silt reservoirs of Vinnitsa region were used. It has been experimentally proved that silts of different species differ significantly in the content of dry matter, humus, individual macro- and trace elements, moisture and acidity, depending on the depth of occurrence. Key words: silts, species and species, chemical composition, physical and chemical properties.
\end{abstract}

\begin{abstract}
Локалізація біогумусу і мінеральних сполук у донних відкладеннях різних видів. Шевчук Т.В., Заволока Г.І. Стаття присвячена вивченню відмінностей у концентрації органічної речовини, гумусу, окремих мінеральних речовин у донних відкладеннях різного виду залежно від глибини залягання, а також після піврічного зберігання озерного мулу в нативних умовах. Експериментально встановлено, що найбільшу кількість гумусу містили змішані водоростеві відкладення. У зразках глинистих донних відкладень донного шару виявлено на 0,18\% менше гумусу порівняно із шаром мулу на відстані 3 м від берега та на $0,92 \%$ порівняно із придонним шаром. За вмістом органічної речовини та загального азоту зразки змішано-водоростевого сапропелю переважали аналогів незалежно від місця залягання. Найбільше органіки містили зразки змішано водоростевого сапропелю придонних зрізів. Аналогічна тенденція зберігалася в динаміці масової частки загального азоту. Найбільше золи виявилося в донних пробах глинистих донних відкладеннях (96,7\% проти 94,8\% - у змішано-водоростевих та 96,5\% - у органічно-піщаних), а найменше - у змішаних водоростевих донних відкладеннях берегової лінії - 86,9\%. Під час вивчення вмісту металів у піщаному сапропелі встановлено, що за вмістом міді зразки донного зрізу перевищували навіть зразки поверхневого шару (різниця становила 0,6\%). Масова частка марганцю в піщаних донних відкладеннях знижувалася залежно від місця залягання, від берегової лінії до придонного шару, а найменше - у зразках донного зрізу. Різниця становила $3,7 \%$ (p $<0,001)$. Солі цинку, навпаки, накопичувалися в донних відкладеннях, а в сухій речовині мулу берегової лінії та донного зрізу відрізнялися на $1,78 \%(\mathrm{p}<0,001)$. Крім того, неоднаковими виявилися і властивості гуматів відповідних важких металів щодо дисоціації, гідролізу та розчинення, отже, евакуації водою із сапропелів. Після зберігання озерний мул вказаного виду ущільнився, змінив забарвлення, набув специфічного, не властивого свіжому сапропелю, запаху, рН становила 6,8 одиниць. За конвекції та дифузного випаровування частина вологи звітрилася. Вміст у сухій речовині органічної, гумусу, азоту, фосфору та калію, відповідно, зріс. Отже, вид, залягання та піврічна витримка в нативних умовах донного відкладення визначає його хімічний склад i властивості. Перспективи подальшого розвитку в цьому напрямі - вивчення хімічних змін у донних відкладеннях різного виду після річного зберігання у природних умовах, з герметизацією або без. Ключові слова: донні відкладення (сапропелі), типи і види, хімічний склад, фізико-хімічні властивості.
\end{abstract}

Локализация биогумуса и минеральных соединений в донных отложениях различных видов. Шевчук Т.В., Заволока Г.И. В статье представлены результаты экспериментальных исследований биохимического состава и свойств сапропелей различных видов. Исследована локализация гумуса, органического вещества и отдельных минералов в сапропелях различных видов в зависимости от глубины залегания. Для анализа были использованы биогенный, кластогенный и смешанный озерный ил водоемов Винницкого района. Экспериментально доказано, что сапропели различных видов существенно отличаются по содержанию сухого вещества, гумуса, отдельных макро- и микроэлементов, показателям влажности и кислотности в зависимости от глубины залегания. Ключевые слова: сапропели, типы и виды, химический состав, физико-химические свойства.

Vinnitsa region has large water resources. Its territory is located in the basins of three major rivers of Ukraine the Southern Bug, the Dniester and the Dnieper, with pools of 62,28 and $10 \%$ respectively. The advantage of the terrain contributed to the emergence of a large number of watercourses and the creation of artificial reservoirs. As you know, for the tributary of the Southern Bug is characterized by a slight inclination of the canal, the tributaries of the Dniester have thresholds. The rivers feed on rain (48\%), snow (25\%) and underground water $(27 \%)$. Water mineralization of calcium bicarbonate. In total on the territory of the oblast flows 3,6 thousand rivers and streams, with a large number of artificial reservoirs - reservoirs and ponds. In particular, the number 
of reservoirs in Vinnitsa region ranks first in Ukraine. In addition, 4.8 thousand artificial reservoirs were built in Vinnitsa oblast: 52 reservoirs with a total area of over 9,6 thousand hectares and 4845 reservoirs occupying 24,1 thousand hectares [1].

The total area of land of the water fund of the Vinnitsa region, according to expert estimates, is more than 114 thousand hectares, including land occupied by water -41 thousand hectares, hydro technical structures -2 thousand hectares, open wetlands -29 thousand hectares, coastal protective strips -42 thousand hectares.

A very characteristic feature of the Southern Bug River basin, which distinguishes it from other major rivers, is a very large overregulation. More than 9,900 artificial reservoirs are created in the basin, their total volume is about $1,5 \mathrm{~km}^{3}$, which is practically equal to the runoff in shallow waters (95\% of supply). The pool has 9755 ponds with a total capacity of 647 million cubic meters. $\mathrm{M}$ and the area of the water mirror 55,3 thousand hectares. The largest number of reservoirs was built in Vinnitsa (3 400), Cherkassy (2 183) and Kirovograd (2 174) areas.

Water resources of Vinnitsa region are considered one of the richest in Ukraine. However, their use and intensive development are not carried out. One of the promising directions of using resources in the water sector is the production of sapropel and river silt. From ancient times, bottom sediments of reservoirs were considered an effective fertilizer, a source of organic matter - humus and minerals. Sapropeli used in the national economy as mulch, raw material for chemical synthesis, feed products $[1 ; 3]$.

An analysis of recent publications has shown that active use of river deposits is in Ukraine. According to a number of scientists $[4 ; 8]$, on the territory of the Rivne region there are sapropels of practically all types, classes and species. The most common are organic clay 1940,7 thousand tons, organic glands - 1949,8 thousand tons, organ sandstone - 1732,4 thousand tons, clay-limestone - 1019,9 thousand tons. Total reserves of the sapropel region, calculated on the basis of inventories of materials and amounted to 139000 thousand UAH tons. At the same time, the balance is 8381,3 thousand tons. Most lake deposits of Sapropel have reserves of more than 100 thousand tons and an area of up to $0,5 \mathrm{~km}^{2}$. The depth of deposits in lakes is quite sufficient for industrial excavations, and the area is acceptable for the use of hydraulic engineering.

According to Yu. Penchuk [5], there are several enterprises in the production and processing of sapropel in Ukraine: "Volynprofos" (Volyn region), "Sapropelcenter" and "Dobrin" (Kyiv region). The total volume of extraction from different sources is from 120 to 200 thousand tons per year.

In the Vinnytsia region, in the urban-type village of Stryzhavka, the Vinnitsa region, samples of river silt, suitable for use as fertilizers, were selected during the purification of the Desenka River and coastal amen- ities. According to the director of the Department of Agrarian Development, Ecology and Natural Resources of the Vinnitsa State Administration M. Tkachuk, the sludge can be used as organic and mineral fertilizers. He showed high content of ash elements, and the acidity of the deposits was optimal for introduction into the soil [3].

In the Kherson region, in the reserve area of the Oleshkovsky Desert, in the experimental zone sapropel began to be used for the enrichment of sandy soils in the cultivation of the Crimean pine. According to V. Tyshchenko, the head of the regional department of forestry and hunting, the Crimean pine began to plant an experimental plot near the village of Nechaev on sapropel. Private plants offered sapropel and developed tree planting technology to preserve seedlings, soil moisture delays, humus of sand and available minerals [6].

As noted by a number of scientists $[2 ; 7]$, river deposits can be used as organic fertilizers. The chemical composition of the sludge in each reservoir can vary considerably. It depends on many parameters: depth, flow rate and other characteristics. In dry matter in the middle bottom sediments contain about $2 \%$ nitrogen, $0,5 \%$ phosphorus and $0,4 \%$ potassium [9]. This exceeds the same indicators of cattle manure. It can be compared with siderites. It is an environmentally friendly product that does not reveal any harmful effects on the human body. Moreover, sludge deposits have the ability to attract harmful substances to themselves, thus purifying the soil and preventing them from getting into plants. One of its main advantages over the manure lies in the fact that the mule decomposes very rapidly in the soil and does not require long composting. In addition, it is an effective stimulant of growth, has a pronounced antiseptic and antimicrobial action, restores normal microflora of the soil. With silt, you can clean the soil from various bacteria, diseases and even pests. It does not have active weed seeds.

River deposits are added to any compost. It will help to disinfect even feces, which makes it possible to quickly obtain absolutely safe fertilizers $[7 ; 11]$.

As scientists point out, the use of sapropel does not preclude the introduction of other types of mineral or organic fertilizers into the soil. The positive result from its use is much longer than the use of humus, and is up to 10-12 years. And even in case of excessive introduction into the soil there are no negative consequences. In addition, river deposits can be used as compost for complex substances: sawdust or bark. It is ideal for heavy soil due to the high content of sand. According to the recommendations of some scientists $[2 ; 10]$, sludge should not be used immediately, as soon as it is removed from the bottom. In order to make it as effective as possible, it should be kept for at least a year. During this time it is oxidized, from humic acids bind and remove the salts of heavy metals. In the future it should be used in sizes up to 3 kilograms per square meter of area. At the efficiency of $1 \mathrm{~kg}$ of river sediment is equivalent to $500 \mathrm{~g}$ of manure. However, the latter is used every 2 years, 
and silt - not more than once every 6 years. The recommended rate of introduction of river silt in the sandyclay soil is $8 \mathrm{~kg} / \mathrm{m}^{2}$, for loam $-4 \mathrm{~kg}$.

In addition, the river mule is mixed with fallen leaves, weeds, vegetable and household waste. Particularly appreciated compost from river silt with chicken waste. It is recommended to add vegetable crops to the following compost: for beets and potatoes $\left(8 \mathrm{~kg}\right.$ per $\left.\mathrm{m}^{2}\right)$, cabbage, carrots, cucumbers $\left(3,5 \mathrm{~kg}\right.$ per $\left.\mathrm{m}^{2}\right)$, tomatoes

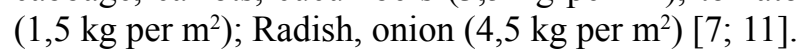

The analysis of recent publications and centuries-old experience shows the importance of bottom sediments and in fact silt. With mules, improving the quality of the soil, increasing its fertility, increasing the immunity of garden crops, accelerating their growth and development. The earth becomes free, breathable, keeps the moisture longer. The content of humus in the fertile soil layer and the activity of beneficial microflora increases, suppresses pathogenic microflora.

From sapropel, river silt differs not only in color, but also in percentage content of nutrients. So, in the latter only $20 \%$ of organic substances, and in sapropel $-97 \%$ [13]. However, many experts consider sapropel varieties of silt. The basic condition, which should correspond to sapropel, - it can not be extracted in reservoirs, where flows of large industrial enterprises take place. Admixtures of heavy metals, harmful and toxic substances can destroy the culture or be deposited in fruits and vegetables, causing irreparable damage to the human body.

Therefore, the study of the chemical composition, properties of sapropel has a great scientific and practical significance. In view of this, the purpose of our research was to study the differences in the concentration of organic matter, humus, individual minerals in sapropel of different species and species, depending on the depth of occurrence and the cut water, as well as after storage.

Material and methods of research. To achieve this goal, the following tasks were formed: to determine the type and type of bottom sediments (sapropels) in separate reservoirs (descents) of the Vinnitsa district; to select samples of lake mud of different species at several points of the fence (near the coast at the point of cutting water and at a distance of $3 \mathrm{~m}$ from it); to study different layers of bottom sediments (bottom sediments, bottom sediments) by chemical composition and properties. After removal, the samples were left in neutralization medium. Six months after storage, the content of dry matter, humus, heavy metals and acidity of sapropel was determined.

The chemical composition and properties of bottom sediments were determined according to the current norms: moisture content - according to GOST 13-85, $\mathrm{pH}$ - according to GOST 17979-88, mass fraction of organic matter - according to GOST 27980-88, mass fraction of ash - according to GOST 26714-85, mass the share of total nitrogen - according to DSTU 71692010 , the mass fraction of total phosphorus - according to GOST 26717-85, the mass fraction of potassium according to GOST 26718-85, the mass fraction of copper - according to DSTU 4770.6-2007, the mass fraction of manganese - according to DSTU 4770.1-2007, the mass fraction of zinc is DSTU 4770.2-2007.

The digital material was statistically processed for $\mathrm{N}$. Plochinsky (1969). The resulting digital data was processed using MS EXEL 98 and Windowse, a statistically processed Student. The results were considered statistically significant at $\mathrm{p}<0,05, \mathrm{p}<0,01, \mathrm{p}<0,001$. In the table material of the work the following symbols were taken: $* \mathrm{p}<0,05, * * \mathrm{p}<0,01, * * * \mathrm{p}<0,001$.

Research results. The most valuable part of bottom sediments is an organic substance, which is formed as a result of biochemical transformation of animal and plant residues. For example, dead plants subsequently form deposits of cellulose, hemicelluloses, low molecular weight carboxylic acids and their salts. Nitrogencontaining macromolecular compounds of plants and animals turn into non-protein compounds, in which amines, amino acids and their derivatives predominate. Nitrogencontaining heterocyclic of the bottom sediments are represented by humic acids. According to various data in the bottom sediments (lake, swamps or river mules), their concentration varies from $4 \%$ to $14 \%$, and in sapropel up to $50-60 \%[2 ; 13]$. The value of humic acids is to create a specific metabolic environment and deposition of individual trace elements. Moving heavy metals, as noted by the council of authors, are not able to dissociate, most of them insoluble in water. Therefore, when the proportion of humus in the bottom sediments increases, their toxicity is reduced as organic fertilizers [8; 14].

Table 1 shows the localization and content of humus in lilies of various types of mules, depending on their place of origin. It has been experimentally established that the largest amount of humus contained a mixed deposition of algae. In addition, a general tendency to increase the humus compounds depending on the place of their occurrence (from the coastline to the lower layer) is established. However, samples of clay bottom sediments of the lower layer revealed $0,18 \%$ less humus than the silt layer at a distance of $3 \mathrm{~m}$ from the coast and $0,92 \%$ compared with the bottom layer.

In our opinion, a decrease in the amount of humus in the lower part of clay mud is due to mass sealing under the pressure of organic deposits and a decrease in the migration of nitrogen-containing compounds to heavy loam. Therefore, in the long run, when harvesting such lake mud, scientific recommendations should be followed: the amount of plowing floor should not exceed $10 \%$.

Study of the biochemical composition of dry matter of bottom sediments has yielded mixed results. Thus, the content of organic substances and common samples of nitrogen, mixed with sapropel of algae, prevailed analogues, regardless of their place of origin. Most of the organic compounds contained samples of mixed algae of the sapropelic bottom. They contain 9,3\% more organic matter compared to organo-sand and $14,5 \%$ - in com- 
parison with clay bottom sediments. A similar trend was observed in the dynamics of the mass fraction of total nitrogen. In particular, the lower section of the mixed sapropel of algae had a higher concentration of nitrogen compared with organically sandy - by $0,12 \%$, and compared with clay - by $0,24 \%$ on a dry matter basis.

It was found that most ash was found in bottom samples of clay deposits (96,7\% vs. $94,8 \%$ in mixed algae and $96,5 \%$ in organic sand). The smallest number of ash elements was found in the mixed bottom sediments of the waterfall of the coastline $-86,9 \%$ on the basis of dry matter (Table 2).
The digital material in Table 2 indicates that the type and location of bottom sediments is determined by their ash composition.

When studying the content of metals in sandy sapropel, it was found that samples of the bottom cut exceeded even the samples of the surface layer by copper content (the difference was $0,6 \%$ ). The mass fraction of manganese in the sandy sediments decreased, depending on the place of occurrence from the coastline to the bottom layer. Mineral salts of manganese were found in samples of the bottom cut. The difference was $3,7 \%(p<0,001)$ (Table 3$)$.

Localization and content of humus in bottom sediments of different species,

Table 1 depending on their place of occurrence, \% in absolutely dry matter, $n=3, M \pm m$

\begin{tabular}{|l|c|c|c|}
\hline \multirow{2}{*}{$\begin{array}{c}\text { Location and depth } \\
\text { of occurrence }\end{array}$} & \multicolumn{3}{c|}{ Types of bottom sediments: } \\
\cline { 2 - 4 } & mixed sludge from algae & organic sandy bottom silt & argillaceous \\
\hline \multicolumn{1}{|c|}{ Coastline } & $4,89 \pm 1,85$ & $3,15 \pm 1,34$ & $2,81 \pm 0,33$ \\
\hline Coastline (3 meters from the coast) & $6,33 \pm 0,05$ & $4,05 \pm 0,15$ & $3,21 \pm 0,18$ \\
\hline Section at the bottom & $8,56 \pm 1,12$ & $4,85 \pm 0,03$ & $3,95 \pm 0,56$ \\
\hline A layer of silt from below & $12,58 \pm 1,83^{*}$ & $6,18 \pm 0,11^{*}$ & $3,03 \pm 1,33$ \\
\hline
\end{tabular}

Chemical composition and properties of sapropels of different species, depending on their place of occurrence, \% in absolutely dry matter

\begin{tabular}{|c|c|c|c|c|c|c|c|c|c|c|c|c|}
\hline \multirow[b]{2}{*}{ Indexes } & \multicolumn{4}{|c|}{$\begin{array}{l}\text { mixed sludge from } \\
\text { algae }\end{array}$} & \multicolumn{4}{|c|}{$\begin{array}{c}\text { organic sandy bottom } \\
\text { silt }\end{array}$} & \multicolumn{4}{|c|}{ argillaceous } \\
\hline & نُ & 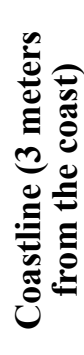 & 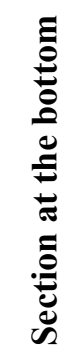 & 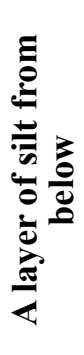 & نُّ & 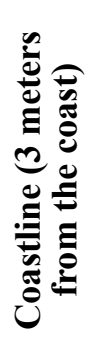 & 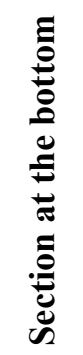 & 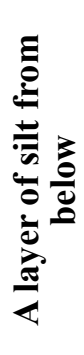 & $\begin{array}{l}\stackrel{\Xi}{\Xi} \\
\tilde{\Xi} \\
\tilde{\Xi}\end{array}$ & 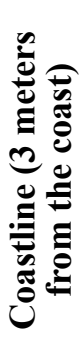 & 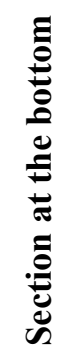 & 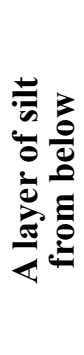 \\
\hline Mass fraction of organic matter & 11,8 & 10,0 & 12,5 & 18,9 & 4,6 & 6,1 & 8,2 & 9,5 & 5,0 & 4,8 & 5,9 & 4,6 \\
\hline Mass fraction of ash & 86,9 & 90,0 & 92,3 & 94,8 & 95,8 & 93,9 & 95,0 & 96,5 & 92,2 & 94,0 & 94,8 & 96,7 \\
\hline Mass fraction of nitrogen & 0,19 & 0,21 & 0,24 & 0,36 & 0,19 & 0,14 & 0,18 & 0,24 & 0,13 & 0,12 & 0,14 & 0,12 \\
\hline $\begin{array}{l}\text { Mass fraction of total phospho- } \\
\text { rus }\left(\mathrm{P}_{2} \mathrm{O}_{5}\right)\end{array}$ & 0,30 & 0,26 & 0,38 & 0,49 & 0,18 & 0,13 & 0,15 & 0,25 & 0,35 & 0,30 & 0,75 & 1,05 \\
\hline $\begin{array}{l}\text { Mass fraction of total potassium } \\
\left(\mathrm{K}_{2} \mathrm{O}\right)\end{array}$ & 1,05 & 1,75 & 1,50 & 1,48 & 0,50 & 0,60 & 0,52 & 0,68 & 2,3 & 2,56 & 3,58 & 4,25 \\
\hline $\begin{array}{l}\text { A mass fraction of calcium } \\
(\mathrm{CaO})\end{array}$ & 0,69 & 0,64 & 0,45 & 0,91 & 2,05 & 0,62 & 1,25 & 2,85 & 6,15 & 6,25 & 8,0 & 10,3 \\
\hline
\end{tabular}

Table 3

The content of heavy metals in sandy sapropel depending on the place of occurrence, $\mathrm{mg} / \mathrm{kg}$ of absolutely dry matter

\begin{tabular}{|l|c|c|c|c|}
\hline \multirow{2}{*}{$\begin{array}{c}\text { Mass fraction } \\
\text { of metal: }\end{array}$} & \multicolumn{4}{|c|}{ Sample point: } \\
\cline { 2 - 5 } & Coastline & $\begin{array}{c}\text { Coastline } \\
\text { (3 meters from the coast) }\end{array}$ & $\begin{array}{c}\text { Section } \\
\text { at the bottom }\end{array}$ & A layer of silt from below \\
\hline Copper & $0,30 \pm 0,002$ & $0,20 \pm 0,010^{* * *}$ & $0,28 \pm 0,012$ & $0,36 \pm 0,009^{* *}$ \\
\hline Manganese & $18,75 \pm 0,015$ & $15,63 \pm 0,030^{* * *}$ & $17,88 \pm 0,005^{* * *}$ & $15,05 \pm 0,006^{* * *}$ \\
\hline Zinc & $1,56 \pm 0,003$ & $1,20 \pm 0,009^{* * *}$ & $1,25 \pm 0,050^{* * *}$ & $3,34 \pm 0,010^{* * *}$ \\
\hline
\end{tabular}


Zinc in the dry substance of the sapropel of the coastline and the lower section differed by $1,78 \%(p<0,001)$. The revealed changes in the localization and levels of accumulation of some heavy metals in sandy deposits indicate the selective ability of humic acids to bind metals. In addition, the properties of humates of the corresponding heavy metals in terms of dissociation, hydrolysis and dissolution and, consequently, evaporation from sapropelic water were uneven.

Taking into account the recommendations of scientists concerning preparation of bottom sediments of lakes for exploitation, one type of slime (organic sand) lasted 180 days. Selected samples were evaluated organoleptically, chemical composition and acidity were determined. Experimentally it was discovered that after storage, the lake of dirt species was densified, the color changed, acquired a specific, not characteristic fresh sapropel, the smell. The acidity of such sapropel was 6.8 units. Due to convection and diffuse evaporation, the humidity was lower. The content of organic matter in the dry matter increased to $75,66 \pm 1,032 \%$, humus - to
$25,9 \pm 0,083 \%$, nitrogen $-2,46 \pm 0,050 \%$, phosphorus $0,21 \pm 0,008 \%$, potassium $-0,13 \pm 0,002 \%$.

Conclusions. The appearance and deposition of bottom sediment determines its chemical composition and properties. A regularity is established between the depth of occurrence and the content of organic matter, humus and nitrogen in lake mud. Most elements of ash are found in bottom sediments of clay type. The localization and dynamics of the content of heavy metals in the bottom sediments is uneven and depends on the depth of occurrence. After six months of storage, the chemical composition and properties of organically sandy deposits are changing.

Prospects for further development in this direction will be directed to studying changes in different types of deposits after annual storage in the natural environment, with or without consolidation. The content of organic matter, humus and dynamics of heavy metals in sapropel after storage was investigated. It will also be interesting to study changes in the composition and properties of sapropel for different methods of melioration.

\section{References}

1. Водні ресурси - БУВР Південний Буг. URL: http://www.buvr.vn.ua/2-buvr/5-vodni-resursi.

2. Ільїн Л. Озерні відклади. Екологічна енциклопедія : у 3 т. / за ред. А. Толстоухова (гол. ред.) та ін. Київ : ТОВ «Центр екологічної освіти та інформації», 2008. Т. 3 : О - Я. С. 17.

3. На Вінниччині річковий мул використовуватимуть як добриво. URL: https://superagronom.com/news/ 4262-na-vinnichchini-richkoviy-mul-vikoristovuvatimut-yak-dobrivo.

4. Пасічний М. Озерний сапропель рівненської області: особливості поширення та ресурси. Науковий вісник Херсонського державного університету. 2018. Вип. 9. С. 163-168.

5. Пенчук Ю. Сапропелеві поклади Придніпровської зони Переяслав-Хмельницького району. Наукові праці НУХT. 2016. T. 22. № 5. С. 33-39.

6. Річковий мул допоможе вижити деревам у пустелі. URL: http://www.golos.com.ua/article/302906.

7. Річковий мул як хороше добриво і його корисні властивості. URL: https://faqukr.ru/novini-ta-suspilstvo/59538-shho-takerichkovij-mul-osoblivosti-ta-korisni.html.

8. Топачевський И. Сапропели пресноводных водоемов Украины. Геология и полезные ископаемые Мирового океана. 2011. № 1. С. 66-72.

9. Genesis, composition, and properties of sapropel sediments. INQUA 501 Seventh Plenary Meeting and Field Trip : Conference, August 2011. DOI: 10.13140/RG.2.2.29059.40485.

10. Concentrations of heavy metal and radioactivity in surface water and sediment of Hazar Lake (Elayig, Turkey) / H. Öymen et al. Chemosphere. 2004. Vol. 55. P. 401-408.

11. Stankevica K., Vincevica-Gaile Z., Klavins M. Freshwater sapropel (gyttja): its description, properties and opportunities of use in contemporary agriculture. Agronomy Research. 2016. № 14 (3). P. 929-947.

12. Stankevica Karina, Klavins Maris, Rutina Liga. Accumulation of Metals in Sapropel. Material Science and Applied Chemistry. 2012. № 26. P. 99-105.

13. Strus O. Study of sapropel extracts from Prybych natural deposits. Journal of Chemical and Pharmaceutical Research. 2015. № 7 (6). P. 133-137.

14. The Study of Lacustrine Deposit (Sapropel) in Belarus. The Chemical Composition and Properties. Journal of Japan Society on Water Environment. № 18 (10). P. 745-754. DOI: 10.2965/jswe.18.745. 